DOI: http://dx.doi.org/10.18203/2320-1770.ijrcog20172383

Case Report

\title{
Gut in the Womb
}

\section{Sandhya Subhash Gadre*, Shweta Meghraj Patel}

Department of Obstetrics and Gynecology, Chirayu Medical College and Hospital, Bhopal, Madhya Pradesh, India

Received: 11 April 2017

Accepted: 08 May 2017

\section{*Correspondence:}

Dr. Sandhya Subhash Gadre,

E-mail: gadre.sandhya@gmail.com

Copyright: (c) the author(s), publisher and licensee Medip Academy. This is an open-access article distributed under the terms of the Creative Commons Attribution Non-Commercial License, which permits unrestricted non-commercial use, distribution, and reproduction in any medium, provided the original work is properly cited.

\begin{abstract}
Dilatation and curettage is one of the common minor procedures with minimal complications but it can cause major complications like perforation of uterus, which is a surgical emergency and the delay in diagnosis and treatment has deleterious consequences for the mother. We are reporting this case of intestinal evisceration \& its strangulation in puerpera after surgical evacuation for retained product of conception. This case is reported as evacuation is a commonly done procedure in puerperium for management of secondary $\mathrm{PPH}$, hence want to emphasize that delay in the diagnosis of complications and management can lead to grave prognosis of the mother.
\end{abstract}

Keywords: Intestinal evisceration, Suction evacuation, Uterine perforation

\section{INTRODUCTION}

$\mathrm{D}$ and $\mathrm{C}$ is performed frequently throughout the world and is considered to be relatively safe. ${ }^{1}$ small bowel obstruction after surgical evacuation due to uterine wall perforation is extremely rare. ${ }^{2}$ Vaginal evisceration is an emergency requiring prompt recognition and surgical intervention. The morbidity is higher when the bowel has become strangulated through the vaginal defect, associated mortality rate is $5.6 \%{ }^{3}$ The incidence of small bowel incarcerated in the uterine wall is $23 \%$. $^{4}$

\section{CASE REPORT}

A 32 years female (P1 L1) was admitted to Chirayu Medical College and Hospital on 15th Aug 2015, with a history of pain in abdomen, vomiting and retching since two days when she had undergone suction evacuation for secondary PPH.

She had a vaginal delivery 40 days back. Then she had secondary PPH 15 days after delivery which subsided after some treatment at local hospital. She continued to have bleeding per vaginum off and on. She was taken to a private hospital where her suction evacuation was performed and was given one blood transfusion. The products were sent for histopathological examination, which were suggestive of placental tissue.

She started having pain in abdomen, distension, retching and vomiting after the procedure. So, she was taken to other private hospital where she received 2 more transfusions and was referred to our centre. We received her after 48 hours of suction evacuation.

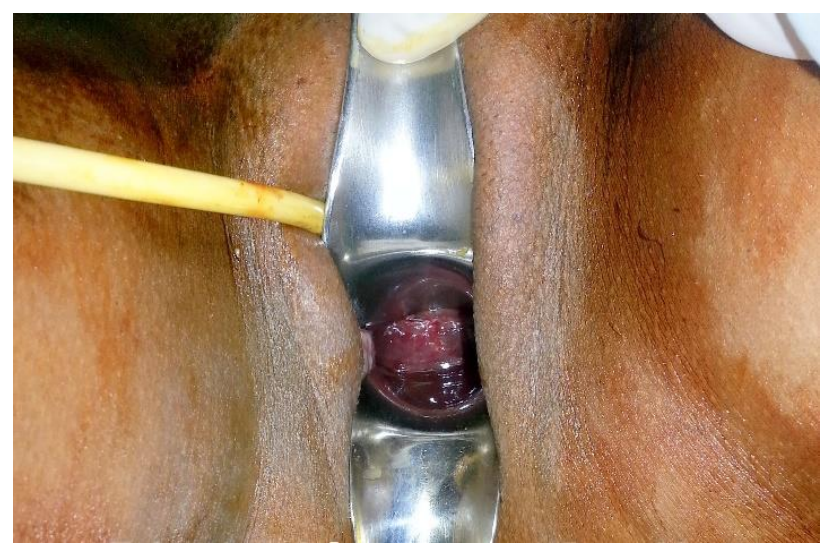

Figure 1: Eviscerated gangerenous bowel loop. 
On admission, she was in agony with excessive abdominal pain, P-104/min, BP 110/70 mm Hg, conj pink, abdomen distended with guarding, rigidity and tenderness. On per speculum examination- gangerenous intestinal loop was seen hanging in vagina, discharge present. Per vaginally no findings could be made out because of guarding and tenderness.

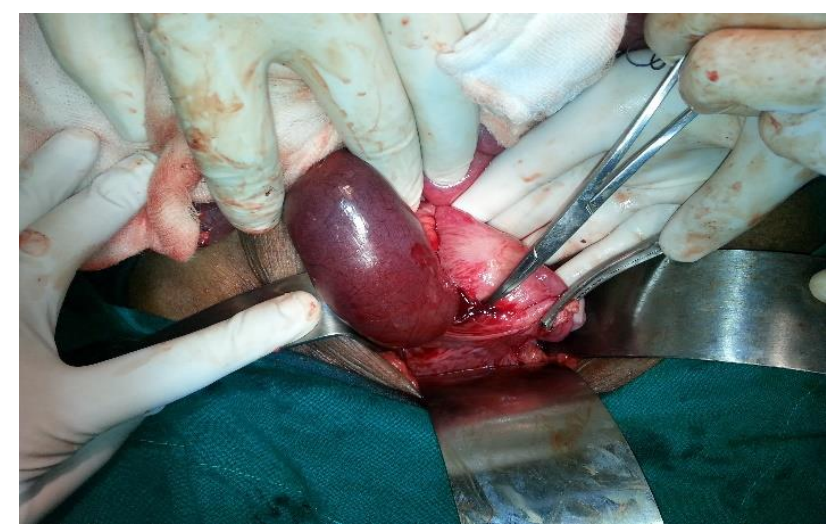

Figure 2: Gangrenous bowel loop entering through the rent in uterus.

\section{Diagnosis}

Intestinal evisceration and its strangulation secondary to uterine damage.

Her $\mathrm{Hb}$ was 8.9 gm\%, TWBC-10,600/cu mm, blood group-O negative, rest all investigations were WNL. She was taken for an emergency laparotomy with a plan of preserving the uterus but with a consent of hysterectomy.

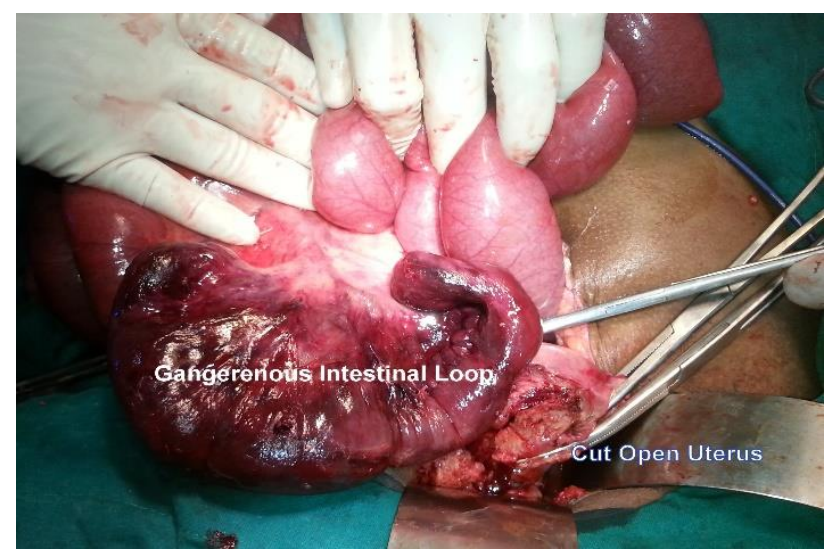

Figure 3: Damage caused to the uterus during delivery of Gangrenous bowel loop.

\section{Intraoperative finings}

At emergency laparotomy, the small intestine was seen entering the uterus from a rent $(3 \times 3 \mathrm{cms})$ anteriorly just below the rt cornu. From where it entered cervical canal and finally in vagina. The bowel was tightly entrapped at the perforation site and at internal os and was oedematous and gangerenous. The bowel loop could not be relieved even after extending the uterine rent. The rent was required to be widened till the internal os. Internal os had to be cut in order to take out the intestine. The damage to the uterus such made was irreparable. $30 \mathrm{~cm}$. loop of small intestine, $1 \mathrm{ft}$ proximal to the ileocaecal junction was oedematous and gangerenous.

\section{Management}

Resection anasotmosis of gangrenous part of small intestine with hysterectomy was done. She made a good recovery and was discharged on $7^{\text {th }}$ postoperative day in a stable condition.

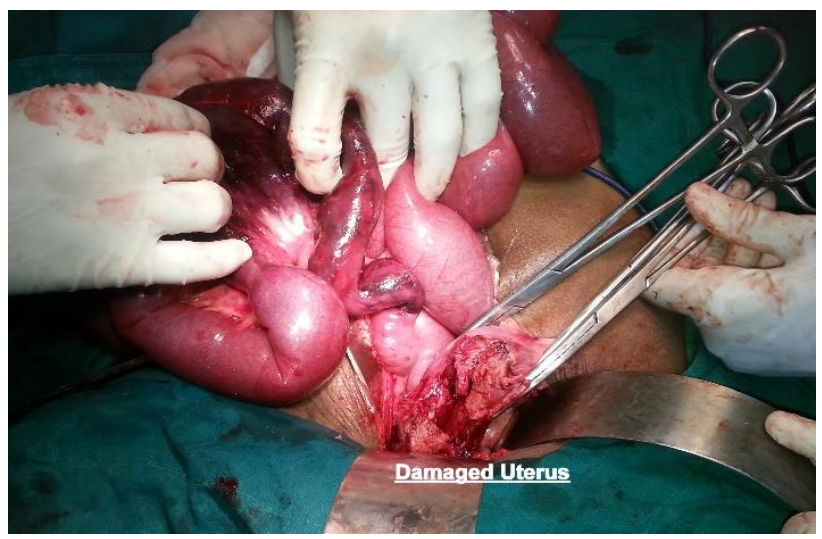

Figure 4: Irreparable damaged uterus.

\section{DISCUSSION}

Most of the perforations of uterus are documented during MTP. This patient was referred to us after 48 hours of evacuation and had attended two hospitals before. The bowel was tightly entrapped at the perforation site and at internal os. It was made still more tight by the uterotonics she had received. Abdominal exploration should be immediately performed if there are signs of severe uterine bleeding or a vascular or visceral injury is suspected..$^{4,6}$ The diagnosis or even suspicion of intrauterine bowel/bladder injury (complicated uterine perforation), however, mandates emergency laparotomy or laparoscopy. She was conservatively managed at previous centres. If patient presents with vaginal evisceration with history of recent surgical evacuation additional diagnostic workup is unnecessary especially when the patient has lost significant amount of blood. Rarely, a hysterectomy is required if the uterus is necrotic or irreparable. ${ }^{4}$ Operator inexperience seems to be the only risk factor in this very common operation (suction evacuation). ${ }^{5}$ Augustin et al recommended publishing of every case on this subject for construction of more precise diagnostic and therapeutic algorithm.

\section{CONCLUSION}

In a scenario of symptoms of bowel obstruction secondary to uterine evacuation, there should be a high index of suspicion. If patient presents with vaginal 
evisceration with history of recent surgical evacuation additional diagnostic workup is unnecessary especially when the patient has lost significant amount of blood. Delay in diagnosis and management affects the outcome adversely. Publishing of every case on this subject for construction of more precise diagnostic and therapeutic algorithm, is important. This may allow for future establishment of guidelines for dealing with this condition.

Funding: No funding sources

Conflict of interest: None declared

Ethical approval: Not required

\section{REFERENCES}

1. Gakhal MS, Levy HM. Sonographic diagnosis of extruded fetal parts from uterine perforation in the retroperitoneal pelvis after termination of intrauterine pregnancy that were occult on magnetic resonance imaging. J Ultrasound Med. 2009;28(12):1723-7.
2. Kim M. Incarcerated omentum with tamponade effect in the uterine perforation scar after dilation and curettage: a case report. J Med Cases. 2014;5(4):2047.

3. Parra RS, Rocha JJ, Feres O. Spontaneous transvaginal small bowel evisceration: a case report.Clinics (Sao Paulo). 2010;65(5) :559-61.

4. Augustin G, Majerović M, Luetić T. Uterine perforation as a complication of surgical abortion causing small bowel obstruction: a review. Archives Gynecol Obstet. 2013;288(2):311-23.

5. Amarin ZO, Badria LF. A survey of uterine perforation following dilatation and curettage or evacuation of retained products of conception Archives Gynecol Obstet. 2005;271(3):203-6.

Cite this article as: Gadre SS, Patel SM. Gut in the womb. Int J Reprod Contracept Obstet Gynecol 2017;6:2678-80. 